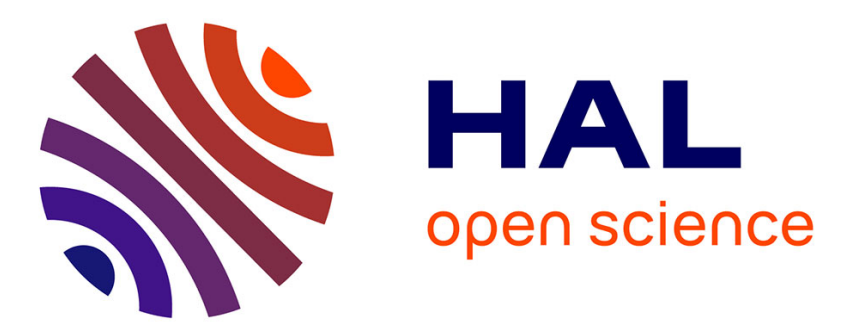

\title{
In vitro oocyte maturation and ovulation in rainbow trout (salmo gairdneri), Northern Pike (Esox lucius), and goldfish (Carassius auratus)
}

Bernard Jalabert

\section{- To cite this version:}

Bernard Jalabert. In vitro oocyte maturation and ovulation in rainbow trout (salmo gairdneri), Northern Pike (Esox lucius), and goldfish (Carassius auratus). Journal of the Fisheries Research Board of Canada, 1976, 33, pp.974-988. hal-01600663

\section{HAL Id: hal-01600663 https://hal.science/hal-01600663}

Submitted on 2 Jun 2020

HAL is a multi-disciplinary open access archive for the deposit and dissemination of scientific research documents, whether they are published or not. The documents may come from teaching and research institutions in France or abroad, or from public or private research centers.
L'archive ouverte pluridisciplinaire HAL, est destinée au dépôt et à la diffusion de documents scientifiques de niveau recherche, publiés ou non, émanant des établissements d'enseignement et de recherche français ou étrangers, des laboratoires publics ou privés. 


\title{
In Vitro Oocyte Maturation and Ovulation in Rainbow Trout (Salmo gairdneri), Northern Pike (Esox lucius), and Goldfish (Carassius auratus)
}

\author{
BERNARD JALABERT \\ Laboratoire de physiologie des poissons, Institut national de la recherche agronomique, \\ 78350 Jouy-en-Josas, France
}

\begin{abstract}
JALABERT, B. 1976. In vitro oocyte maturation and ovulation in rainbow trout (Salmo gairdneri), northern pike (Esox lucius), and goldfish (Carassius auratus). J. Fish. Res. Board Can. 33: 974-988.
\end{abstract}

The endocrine processes which control oocyte maturation (resumption of meiosis) and ovulation have been studied in vitro in the trout Salmo gairdneri. Follicular maturation is ultimately under the control of a pituitary gonadotropin which induces the follicle to synthesize specific steroids; these steroids act in turn directly on the oocyte to promote maturation. The systematic study of the in vitro efficiency of various steroids have shown that $17 \alpha$-hydroxy$20 \beta$-dihydroprogesterone plays a preferential role in initiating maturation; this steroid has a high affinity for a plasma protein system. The efficiency of this steroid, similarly to the efficiency of the gonadotropin, can be modulated by other circulating steroids, The precise chronology of some events of follicle maturation have been defined using inhibitors of protein and RNA synthesis.

The ovulatory process (sensu stricto: expulsion of matured oocyte from the follicular envelopes) has been experimentally dissociated from oocyte maturation, and some mediators likely to act on ovulation have been identified.

These data permit the consideration of novel means of intervention at the ovarian level to synchronize maturation and ovulation in fish, in order to give new tools for progress in aquaculture.

JALABERT, B. 1976. In vitro oocyte maturation and ovulation in rainbow trout (Salmo gairdneri), northern pike (Esox lucius), and goldfish (Carassius auratus). J. Fish. Res. Board Can. 33: 974-988.

Nous avons étudié in vitro les processus endocrines qui contrôlent la maturation des ovocytes (reprise de la méiose) et l'ovulation chez la truite arc-en-ciel, Salmo gairdneri. La maturation folliculaire est en dernier lieu sous le contrôle d'une gonadotropine hypophysaire qui déclenche dans le follicule la synthèse de stéroïdes spécifiques; ces stéroïdes, à leur tour, agissent directement sur l'ovocyte et activent la maturation. L'étude systématique de l'efficacité in vitro de divers stéroïdes démontre que la $17 \alpha$ hydroxy-20 $\beta$ dihydroprogestérone joue un rôle préférentiel dans l'amorçage de la maturation; ce stéroïde a une haute affinité pour un système de protéines plasmiques. L'efficacité de ce stéroïde, tout comme celle de la gonadotropine, peut être modulée par d'autres stéroïdes en circulation. Nous avons défini, à l'aide d'inhibiteurs de protéines et synthèse de la RNA, la chronologie précise de certaines étapes de maturation des follicules.

Le processus d'ovulation (sensu stricto: expulsion de l'ovocyte mûr des enveloppes folliculaires) a été dissocié expérimentalement de la maturation de l'ovocyte, et certains médiateurs susceptibles d'activer l'ovulation ont été identifiées.

Grâce à ces données, on peut considérer de nouveaux moyens d'intervenir au niveau ovarien pour synchroniser la maturation et l'ovulation chez les poissons, fournissant ainsi de nouveaux outils pour le progrès de l'aquiculture.

OOCYTE maturation (structural and biochemical modifications which develop simultaneously with resumption of meiosis) and ovulation (emission of the denuded oocyte from the follicle) are processes that mark the end of oogenesis and pre-

Printed in Canada (J4005)

Imprimé au Canada (J4005) pare the oocyte for fertilization and embryonic development. In aquacultured fish, it is often necessary and advantageous to artificially induce these processes in order to better control reproduction conditions. In current practice, this may be done by injection of exogenous pituitary extracts (hypophysation) which simulate endogenous ovulatory discharge. It is difficult in this 
intervention to estimate the most favorable stage of maturity for successful treatment, a stage which will, in fact, determine egg quality.

Studying phenomena that occur in the ovaries and follicles after "maturing and ovulating" gonadotropic stimulation, we may find better methods of intervention which are adapted to different states of ovarian maturity. In vitro methods of incubating follicles or ovary fragments lend themselves well to such research in fishes, the ovaries usually providing a large number of synchronous follicles which can be used in systematic assays of biologically active substances.

As in amphibians (Schuetz 1974), these in vitro study techniques have shown that gonadotropic action of the pituitary is probably mediated by direct steroid action on oocyte maturation in Misgurnus fossilis (Kirshenblatt 1959); in sturgeon, Acipenser stellatus (Dettlaff and Skoblina 1969); in Indian catfish, Heteropneustes fossilis (Goswami and Sundararaj 1971b); in medaka, Oryzias latipes (Hirose 1971; Iwamatsu 1974); in rainbow trout, Salmo gairdneri (Jalabert et al.); in goldfish Carassius auratus (Jalabert et al. 1973) and in northern pike Esox lucius (Jalabert and Breton 1973).

However, according to the species studied and the authors, conclusions are contradictory as to the nature of active steroids, their site of production, and the link between in vitro maturation and ovulation.

Thus, the more efficient steroids in $H$. fossilis are considered to be corticosteroids in a specific concentration ratio (Sundararaj and Goswami 1971). In O. latipes cortisol seems more efficient than progesterone when these steroids are added and left in the incubation medium (Hirose 1972); when follicles are treated by $10-\mathrm{min}$ immersion in a solution of these steroids, then washed before incubation, progesterone is the most efficient (Iwamatsu 1974). In trout, $17 \alpha$-hydroxy-20 $\beta$-dihydroprogesterone $(17 \alpha-20 \beta \mathrm{Pg})$ seems to be the strongest inducer of in vitro oocyte maturation (Fostier et al. 1973). This is also true in pike (Jalabert and Breton 1973). We will see that the same is also true in goldfish.

The production site of active steroid(s) is, of course, the ovary, and especially the follicle in trout, as shown by the positive action of in vitro gonadotropic extracts on the oocyte + follicle (+ fragments of ovarian tissue) system (Jalabert et al. 1972). In $H$. fossilis, on the contrary, gonadotropic extracts seem to have no effect on follicles in vitro (Goswami and Sundararaj 1971b; Sundararaj et al. 1972b), and different experimental facts favor the hypothesis of a gonadotropic relay by the interrenal organ which would produce corticosteroids with specific action on maturation (Sundararaj and Goswami 1974).

The situation in $O$. latipes is more ambiguous where it is hypothesized that the maturation mediator is a corticosteroid (Hirose 1972) since the gonadotropic extract acts on the follicle in vitro (Hirose 1971, 1972). However, Colombo et al. (1973) have shown that fish ovary can synthesize corticosteroids. Whatever the mediator may be, this species does not seem to need direct interrenal intervention. In goldfish, we left open the possibility of interrenal organ participation in maturation release (Jalabert et al. 1973). We will discuss here in detail that involvement by comparing it to that of trout and pike.

As concerns ovulation in trout, we observed experimental dissociation between the mechanisms of oocyte maturation and ovulation, showing that these processes are directly controlled by distinctly different mediators (Jalabert et al. 1972). The absence of spontaneous ovulation in vitro at the end of maturation suggests that the relay producing the ovulatory mediator(s) is absent in the system in incubation. On the other hand, in $H$. fossilis, ovulation occurs in vitro at the end of maturation induced by corticosteroids (Goswami and Sundararaj 1971a, b) and in $O$. latipes at the end of maturation induced by steroids (Hirose 1971; Iwamatsu 1974) or by gonadotropic extracts (Hirose 1971; Hirose and Donaldson 1972). We thus tried to examine more thoroughly rainbow trout, goldfish, and northern pike to find out if trout was an isolated example or not.

The data given here constitute a synthesis of results obtained by our laboratory on the problem of oocyte maturation and ovulation in rainbow trout, goldfish, and northern pike mentioned above. The most detailed experiments were done on rainbow trout. Trials carried out on goldfish and northern pike only attempted to extend the essential points established in the trout model.

\section{Methods}

Technical details on incubation methods have already been given in previous publications and reference will be made to them in this text. Only points of general methodology and some modifications will be mentioned here. Species used in these studies are rainbow trout (Salmo gairdneri), northern pike (Esox lucius), and goldfish (Carassius auratus).

In rainbow trout, follicles (4-6 $\mathrm{mm}$ diam) containing oocytes at the final stage of "peripheral germinal vesicle" were incubated at 10 or $15 \mathrm{C}$ in lots of 25 in $2 \mathrm{ml}$ of trout balanced salt solution 
(TBSS). Northern pike follicles $(2-2.5 \mathrm{~mm}$ diam) at the same stage were incubated at $12 \mathrm{C}$ in lots of $40-50$ in $2 \mathrm{ml}$ of TBSS. Goldfish oocytes were incubated at $25 \mathrm{C}$ in lots of 50-100 follicles $(1 \mathrm{~mm}$ mean diam) in $1 \mathrm{ml}$ carp balanced salt solution (CBSS) (Jalabert et al. 1973).

At the end of incubation (3-5 days in trout, depending on temperature and maturing agent; $24 \mathrm{~h}$ in goldfish and $40-60 \mathrm{~h}$ in northern pike), the proportion of mature oocytes was estimated using as criteria germinal vesicle breakdown (GVBD) or for large numbers, the simple criterion of vitellin maturation (apparent change in vitellus structure). In trout, each maturing treatment was characterized by the Median Efficient Dose (MED), the theoretical dose giving $50 \%$ maturation calculated by the method described for biological assay of fish gonadotropic hormones (Jalabert et al. 1974) and also applicable to steroid treatment.
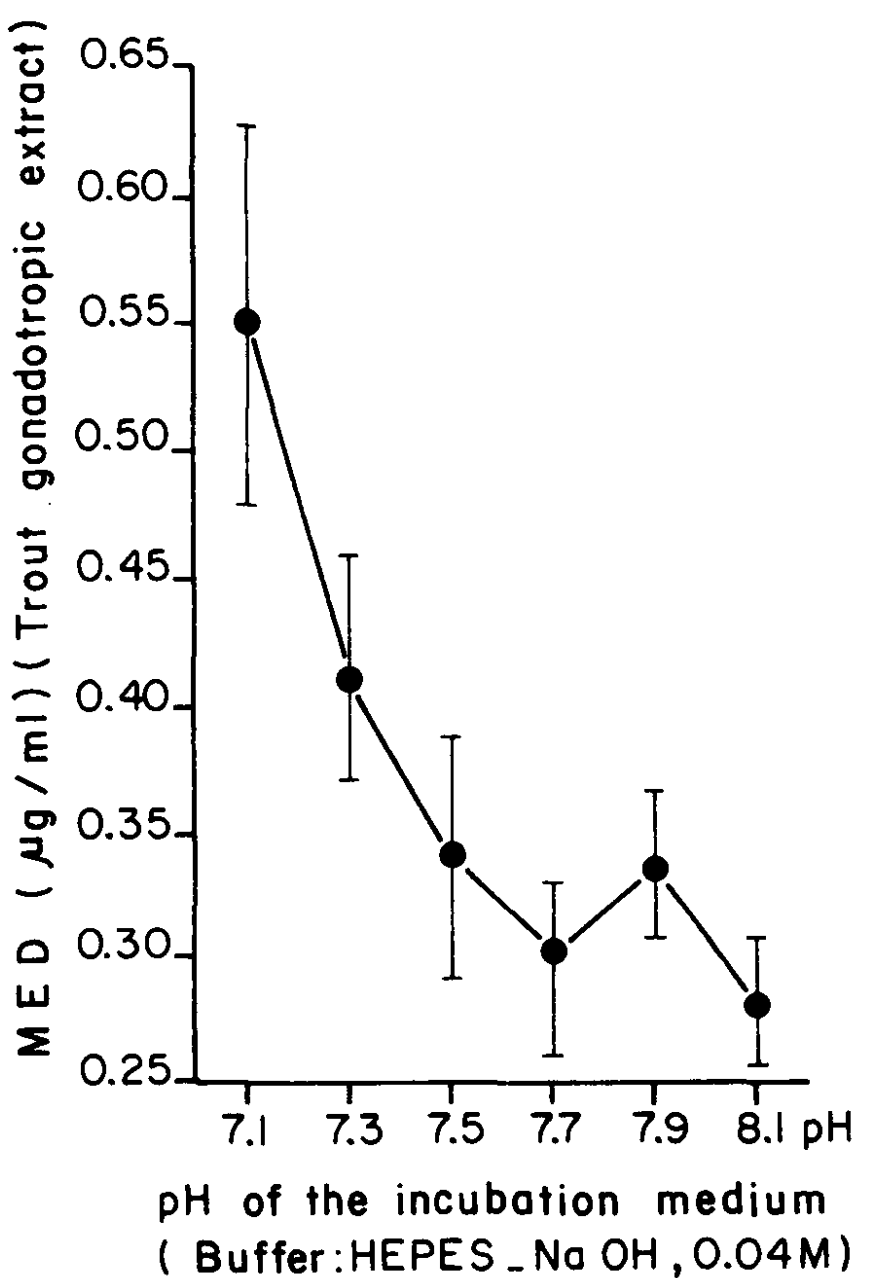

FIG. 1. Effect of pH of the incubation medium on the median efficient dose (MED) of a trout gonadotropic extract on intrafollicular oocyte maturation in rainbow trout (Salmo gairdneri). Lower MED indicates higher efficiency on maturation. Vertical bars show confidence limits at the $95 \%$ level of probability. Figure has been drawn from data concerning follicles of the same fish.
Since the first report on the composition of trout and carp balanced solutions, these media have been modified by suppressing $\mathrm{NaH}_{2} \mathrm{PO}_{4}$, adding penicillin $(100,000 \mathrm{U} /$ liter $)$ and streptomycin sulfate $(100,000$ $\mathrm{mcg} / \mathrm{liter}$ and raising the $\mathrm{pH}$ to 8 . This was done either by changing the bicarbonate concentration for incubation under $1 \% \mathrm{CO}_{2}$, or by replacing bicarbonate with HEPES- $\mathrm{N}_{\mathrm{a}} \mathrm{OH}$ buffer $(0.04 \mathrm{M}, \mathrm{pH} 8)$ for incubation under atmosphere without $\mathrm{CO}_{2}$. The $\mathrm{pH}$ of the incubation medium was increased after study of the efficiency of gonadotropic extracts on intrafollicular maturation as related to $\mathrm{pH}$, showing an optimum of about pH 8 in trout (Fig. 1) and goldfish (Fig. 2). These high $\mathrm{pH}$ values seem physiological in some fish as shown by arterial $\mathrm{pH}$ measurements in trout (Cameron and Randall 1972).

Fish gonadotropic extracts mentioned in text, tables, and figures have been prepared by methods previously described (Jalabert et al. 1974). SG-G100, a partially purified salmon gonadotropin, was the generous gift of E. M. Donaldson (Fisheries Research Board of Canada). t-Gth, trout gonadotropic hormone, is a highly purified gonadotropic hormone prepared by Breton et al. (1976b), using the in vitro intrafollicular oocyte maturation test in trout (Jalabert et al. 1974).

Steroids currently mentioned in the text, tables, and figures are abbreviated as follows:

\begin{tabular}{|c|c|}
\hline $17 \alpha-20 \beta \mathrm{Pg}$ & $\begin{array}{l}17 \alpha \text {-hydroxy-20 } \beta \text {-dihydropro- } \\
\text { gesterone ( } 4 \text { pregnen- } 17 \alpha \\
20 \beta \text { diol-3 one) }\end{array}$ \\
\hline $20 \beta \mathrm{Pg}$ & 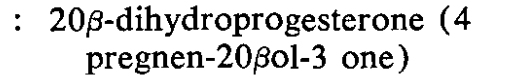 \\
\hline $17 \alpha \mathrm{Pg}$ & $\begin{array}{c}: 17 \alpha \text {-hydroxyprogesterone ( } 4 \\
\text { pregnen-17 } \alpha \text { ol-3 one })\end{array}$ \\
\hline Cortisol & $\begin{array}{l}\text { : (4 pregnen-11 } \beta, 17 \alpha, 21 \text { triol- } \\
3,20 \text { dione })\end{array}$ \\
\hline cortisone & $\begin{array}{l}:(4 \text { pregnen-17 } \alpha, 21 \text { diol- } 3,11, \\
20 \text { trione })\end{array}$ \\
\hline corticosterone & $\begin{array}{l}\text { : (4 pregnen-11 } \beta, 21 \text { diol-3,20 } \\
\text { dione) }\end{array}$ \\
\hline $\begin{array}{l}\text { DOC or } \\
\text { 11-deoxy- } \\
\text { corticosterone }\end{array}$ & : (4 pregnen-21 ol-3,20 dione) \\
\hline $\begin{array}{l}\text { 11-deoxycortisol } \\
\text { cortexolone }\end{array}$ & $\begin{array}{l}\text { (4 pregnen-17 } \alpha, 21 \text { diol-3,20 } \\
\text { dione) }\end{array}$ \\
\hline
\end{tabular}

\section{Results and Discussion}

\section{Oocyte Maturation}

a) Trout - Maturation of trout oocytes incubated in their follicle may be induced by fish gonadotropic extracts and hormones and by numerous steroids belonging essentially to the progestagen group (Jalabert et al. 1972; Jalabert et al. 1974). All the "maturing agents" may be classified according to the criteria shown in Table 1:

1) direct action on oocyte or indirect action by follicle intermediary; 2) minimum exposure time 
TABlE 1. Classification of different hormones active in intrafollicular oocyte maturation in rainbow trout (Salmo gairdneri).

\begin{tabular}{|c|c|c|c|c|}
\hline $\begin{array}{l}\text { Classification } \\
\text { criterion }\end{array}$ & $17 \alpha-20 \beta \mathrm{Pg}$ & $20 \beta \mathrm{Pg}$ & $\begin{array}{l}\text { Progesterone } \\
\qquad(P g)\end{array}$ & $\begin{array}{l}\text { Trout gonadotropin } \\
\qquad(t-G t h)\end{array}$ \\
\hline $\begin{array}{l}\text { Direct or indirect action } \\
\text { on denuded oocyte }\end{array}$ & \multicolumn{2}{|c|}{$\begin{array}{l}\text { Maturation of denuded } \\
\text { ooctyces }\end{array}$} & \multicolumn{2}{|c|}{$\begin{array}{l}\text { No action on denuded } \\
\text { oocytes }\end{array}$} \\
\hline $\begin{array}{l}\text { Minimum duration of } \\
\text { exposure to an excess of } \\
\text { hormone to obtain } 100 \% \\
\text { maturation }(10 \mathrm{C})\end{array}$ & $30 \mathrm{~s}$ to $15 \mathrm{~min}$ & (no assay) & $30 \mathrm{~min}$ to $2 \mathrm{~h}$ & $1 \mathrm{~h} 30$ to $3 \mathrm{~h}$ \\
\hline $\begin{array}{l}\text { Mean duration of incubation } \\
\text { at } 10 \mathrm{C} \text { with an excess of } \\
\text { hormone to observe } 100 \% \\
\text { maturation (germinal vesicle } \\
\text { breakdown) }\end{array}$ & $\simeq 60 \mathrm{~h}$ & $\simeq 60 \mathrm{~h}$ & $\simeq 60 \mathrm{~h}$ & $\simeq 72 \mathrm{~h}$ \\
\hline $\begin{array}{l}\text { Range of values for the median } \\
\text { efficient dose (MED) } \\
\text { (continuous exposure) }\end{array}$ & 5 to $90 \mathrm{ng} / \mathrm{ml}$ & from $15 \mathrm{ng} / \mathrm{ml}$ & 150 to $500 \mathrm{ng} / \mathrm{ml}$ & 50 to $200 \mathrm{ng} / \mathrm{ml}$ \\
\hline
\end{tabular}

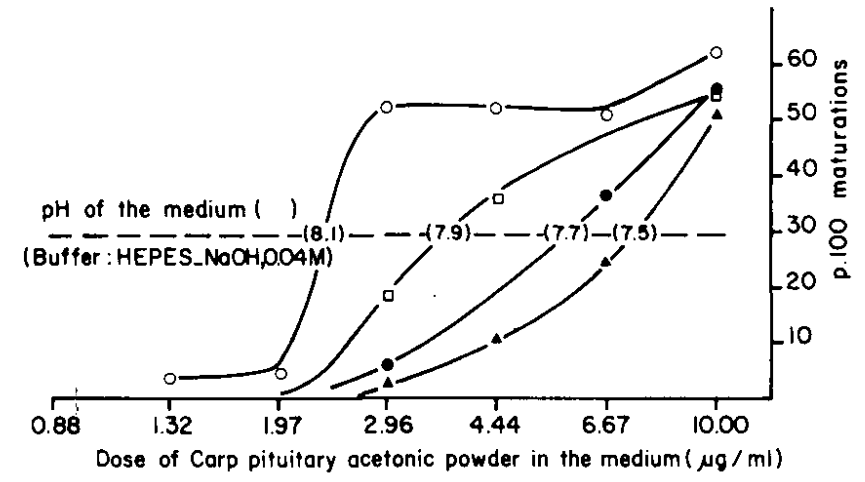

FIG. 2. Relation between dose of carp pituitary extract and percentage of intrafollicular oocyte maturation in goldfish (Carassius auratus) at various $\mathrm{pH}$ of the incubation medium. Each percentage is calculated from a lot of 50-100 follicles, and all data concern follicles of the same fish.

to hormone excess ( $1 \mu \mathrm{g}$ steroid or $1 \mu \mathrm{g} / \mathrm{ml}$ trout purified gonadotropic hormone t-Gth) to obtain $100 \%$ maturation; 3) mean incubation time with hormone excess to obtain $100 \%$ maturation; 4) range of values of the MED. The last three parameters vary greatly among females and are only indications; they are, however, sufficient to establish a classification. $17 \alpha-20 \beta \mathrm{Pg}$ is always the most efficient steroid (Fostier et al. 1973), followed by $20 \beta \mathrm{Pg}$, which is slightly less active (on the oocytes of the same female the same hierarchy is always observed: $\mathrm{MED}(17 \alpha-20 \beta \mathrm{Pg})<\mathrm{MED}$ $(20 \beta \mathrm{Pg}$ ). Moreover, these two steroids are the only ones that continue to exert a maturing activity on naked oocytes, thus showing direct action. On the other hand, the presence of follicular envelops is necessary to induce oocyte matura- tion by other steroids found up to now acting on intrafollicular maturation. Moreover, they are much less efficient (MED higher than $150 \mathrm{ng}$ in continuous exposure, and minimum exposure time to obtain $100 \%$ maturation is $30 \mathrm{~min}-2 \mathrm{~h}$ as against $30 \mathrm{~s}-15 \mathrm{~min}$ for $17 \alpha-20 \beta \mathrm{Pg}$ ). Their action, however, is different from that of gonadotropic hormone, which needs the presence of follicular envelopes, since mean incubation time to obtain $100 \%$ maturation is about $60 \mathrm{~h}$ with progesterone (as for $17 \alpha-20 \beta \mathrm{Pg}$ and $20 \beta \mathrm{Pg}$ ), while it is about $72 \mathrm{~h}$ with the gonadotropic hormone $\mathrm{t}-\mathrm{GtH}$.

Complementary information is obtained by studying the effect of m-RNA biosynthesis inhibitors and protein biosynthesis inhibitors on the action of these hormones (B. Jalabert and A. Fostier unpublished data). When these inhibitors are added to the incubation medium at the same time as different hormones, the following results are obtained (Table 2):

1) Actinomycin $\mathrm{D}$ and mitomycin $\mathrm{C}$, m-RNA biosynthesis inhibitors (transcription DNAmRNA), completely stop t-GtH gonadotropic hormone action, but have no effect on the action of $17 \alpha-20 \beta \mathrm{Pg}$ or $20 \beta \mathrm{Pg}$, and partially inhibit progesterone action.

2) Cycloheximide, protein synthesis inhibitor (translation m-RNA-proteins) (theoretically by inhibiting ribosome translocation), completely stops all maturing hormone action, while puromycin, another protein synthesis inhibitor (by theoretically stopping polypeptidic chain elongation), completely inhibits only t-GtH action, does not stop $17 \alpha-20 \beta \mathrm{Pg}$ action, and partially inhibits that of progesterone. 


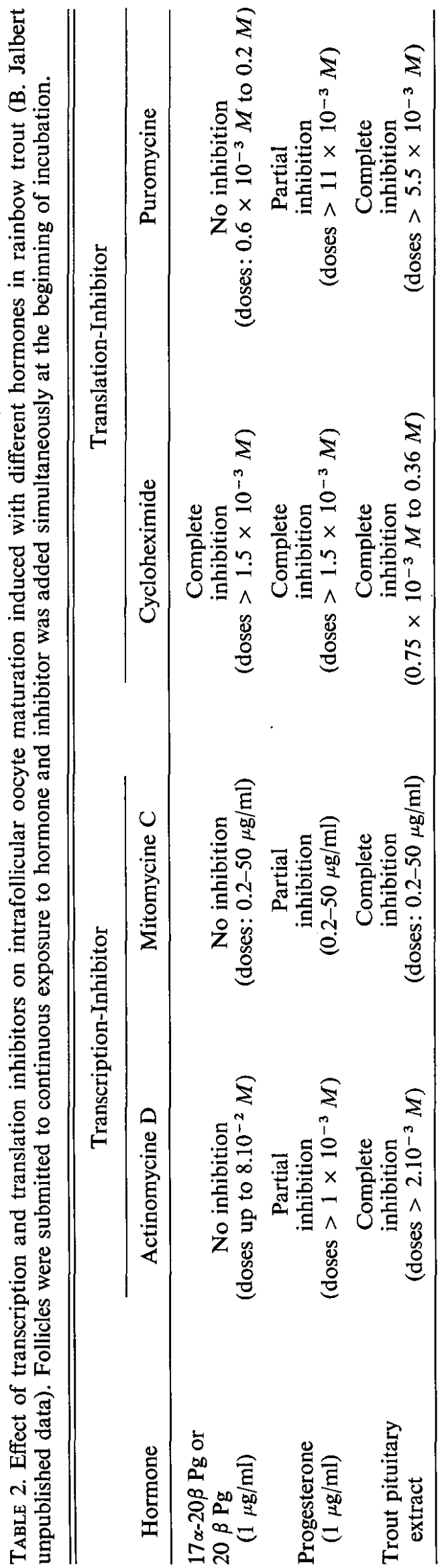


(3)

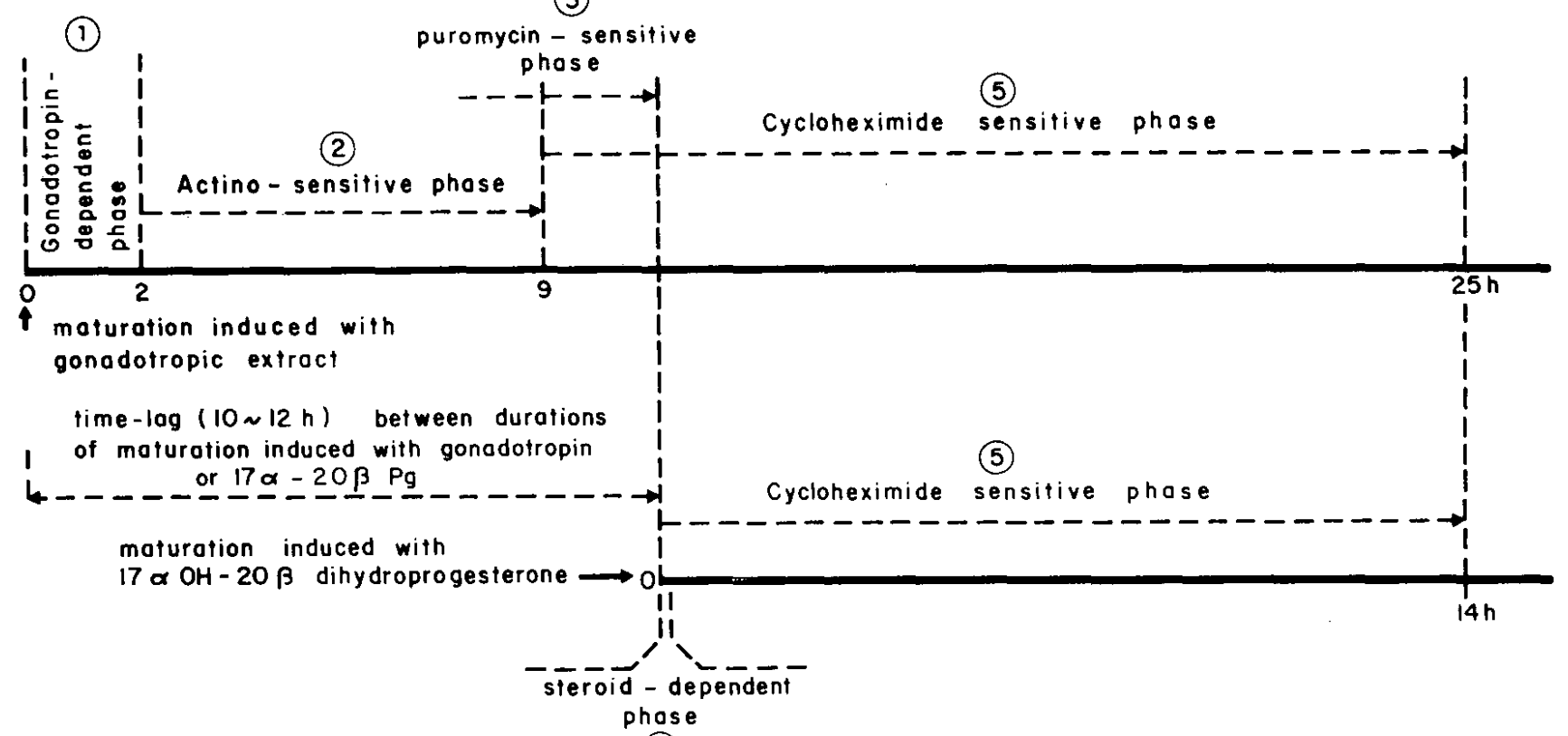

(4)

Fig. 3. Chronology of some processes occurring in trout follicles after initiation by gonadotropin or $17 \alpha$ $20 \beta \mathrm{Pg}$ action in vitro, and characterized by hormone dependency or sensitivity to inhibitors of m-RNA synthesis (actinomycin D) or protein synthesis (puromycin and cycloheximide) (B. Jalabert unpublished data).

The addition of these inhibitors to the incubation medium at increasing times after the onset of t-GtH or $17 \alpha-20 \beta \mathrm{Pg}$ action furnishes information on the length and succession of sensitive phases. Using these data, when compared to those in Table 1, we can show the chronology of the processes following gonadotropic hormone action on the follicular envelopes (Fig. 3):

Follicular stages: the processes occurring in follicular envelope cells ( 0 to $10-12 \mathrm{~h}$ after onset of gonadotropin action).

1) activation of gonadotropic receptors;

2) m-RNA synthesis;

3) protein synthesis, sensitive both to puromycin and cycloheximide, probably leading to elaboration of steroidogenesis-specific enzymes, then to the production of maturation steroid(s).

Oocyte stages:

4) activation of steroid receptors;

5) protein synthesis preparatory to maturation, sensitive to cycloheximide and not to puromycin.

Indirect action in vitro of some steroids on intrafollicular maturation induced by $17_{\alpha}-20 \beta \mathrm{Pg}$ or a gonadotropic extract (Jalabert 1975)

Some steroids that have no maturing activity in vitro at doses lower than $1 \mu \mathrm{g} / \mathrm{ml}$ have proven capable of modifying MED and thus $17 \alpha-20 \beta \mathrm{Pg}$ or gonadotropic extract efficacy.

- Oestradiol and oesterone slightly increase gonadotropic extract MED, thus diminishing its effectiveness (to significance limit). On the other hand, testosterone increases this efficiency (2 times). As these steroids have no significant effect on maturation induced by $17 \alpha-20 \beta \mathrm{Pg}$ their action site is probably to be found in the follicle envelopes.

- Corticosteroids, and particularly cortisol and cortisone, increase gonadotropic extract efficacy (2-6 times), but multiply the effectiveness of $17 \alpha-20 \beta \mathrm{Pg}$ by a still higher factor, which may reach 11-13, depending on the females. This suggests direct effect of these corticosteroids on oocyte sensibilization to $17 \alpha-20 \beta \mathrm{Pg}$ action.

b) Goldfish and pike $-17_{\alpha-20 \beta} \mathrm{Pg}$ action on intrafollicular maturation - In northern pike $17 \alpha-20 \beta \mathrm{Pg}$ was also found to be the most potent steroid able to induce intrafollicular oocyte maturation (Jalabert and Breton 1973) with a MED near $30 \mathrm{ng} / \mathrm{ml}$, followed in the range of $150-400$ $\mathrm{ng} / \mathrm{ml}$, by $20 \beta \mathrm{Pg}$, DOC, progesterone, $17_{\alpha} \mathrm{Pg}$, and pregnenolone (Fig. 4).

11-deoxycortisol was found to be the most potent in goldfish before $17 \alpha-20 \beta \mathrm{Pg}$ was available (Jalabert et al. 1972). In fact, as soon as 


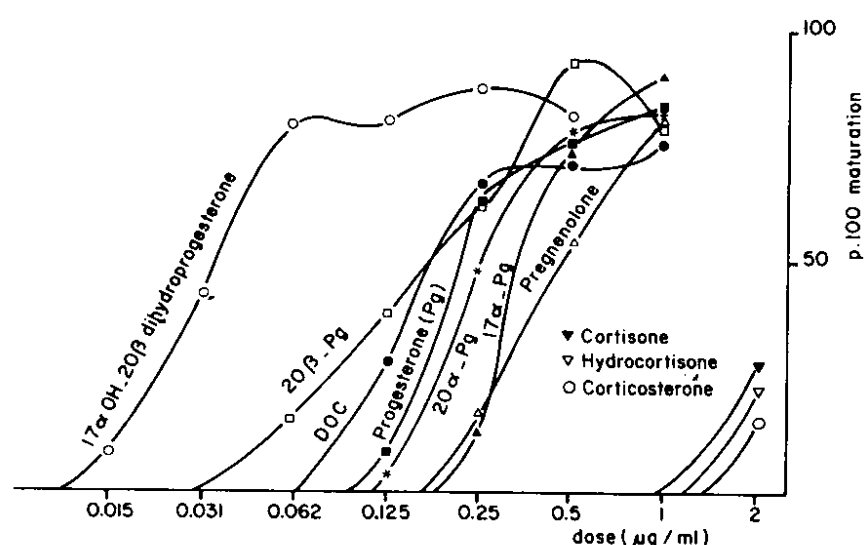

FIg. 4. Percentage of intrafollicular oocyte maturation in northern pike (Esox lucius) as a function of the dose of some steroids. Each percentage is calculated from a lot of 40-50 follicles and all data concern follicles of the same fish.

$17 \alpha-20 \beta \mathrm{Pg}$ could be assayed, it exhibited the lowest MED (near $30 \mathrm{ng} / \mathrm{ml}$ ), and thus the best efficiency, in this species also (Fig. 5).

\section{Cortisol action on gonadotropin extract efficiency}

In goldfish and northern pike (Fig. 6, 7), adding cortisol to the incubation medium considerably increases gonadotropin extract effectiveness, as in trout. The effect of cortisol on $17 \alpha-20 \beta \mathrm{Pg}$ efficiency has not been tested.

\section{Ovulation}

a) Trout - A previous observation (Jalabert et al. 1972) showed that some coelomic fluids, sampled at the time of ovulation and used as incubation media, could induce ovulation inde-

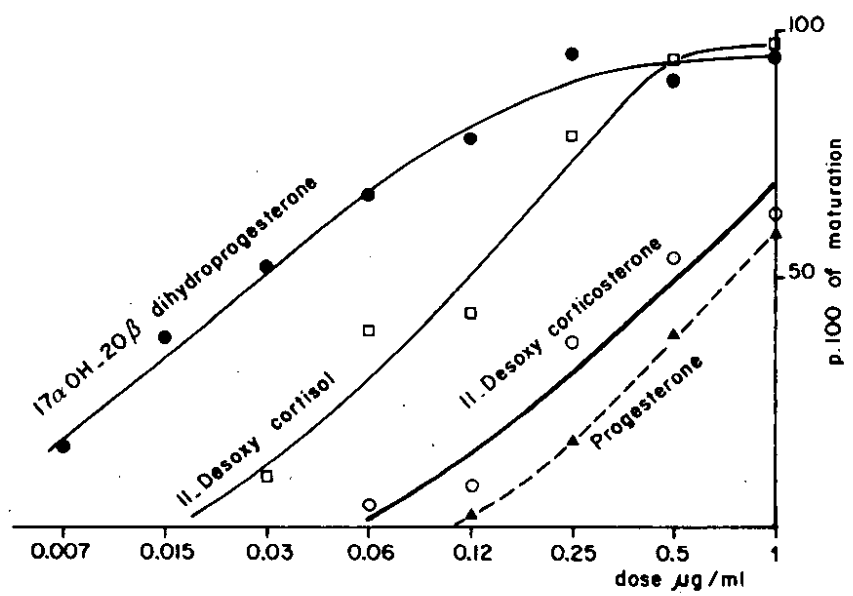

FIG. 5. Percentage of intrafollicular oocyte maturation in goldfish as a function of the dose of some steroids. Each percentage is calculated from a lot of 50-100 follicles and all data concern follicles of the same fish.

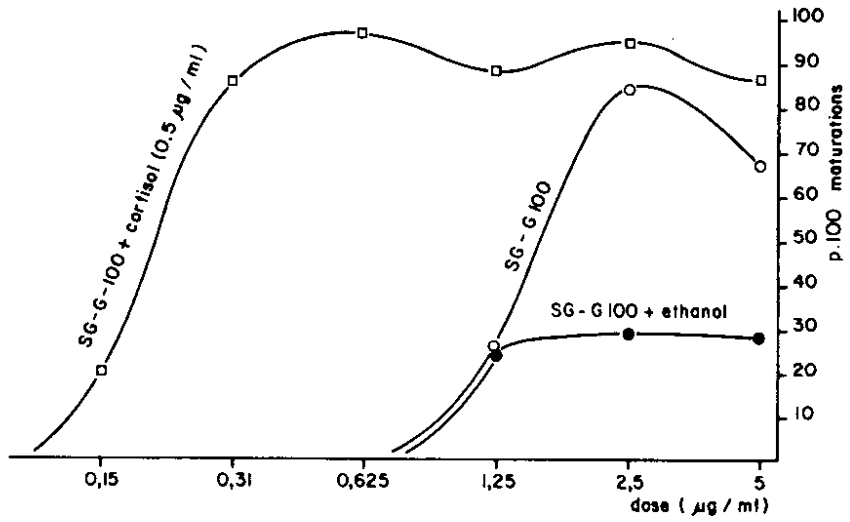

FIG. 6. Action of cortisol $(0.5 \mu \mathrm{g}$ in ethanol) on the percentage of intrafollicular oocyte maturation in pike as a function of the dose of salmon gonadotropic extract SG-G 100. Each percentage is calculated from a lot of 40-50 follicles and all data concern follicles of the same fish.

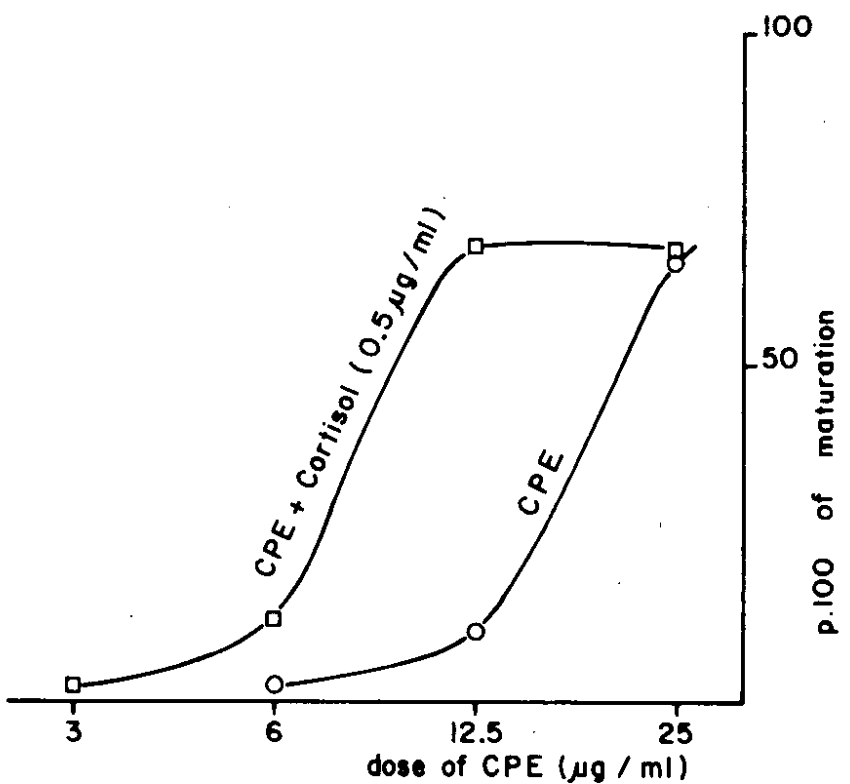

FIg. 7. Action of cortisol $(0.5 \mu \mathrm{g} / \mathrm{ml})$ on the percentage of intrafollicular oocyte maturation in goldfish as a function of the dose of carp pituitary extract (CPE). Each percentage is calculated from a lot of 50-100 follicles and all data concern follicles of the same fish.

pendently of oocyte maturation. This independence between maturation and ovulation thus implies the involvement of distinct mediators produced successively.

Moreover, maturation in vitro is seldom followed by spontaneous ovulation, whether it be triggered in vitro (by gonadotropin extract or $17 \alpha^{-20} \beta \mathrm{Pg}$ ) or whether follicles are placed in vitro at any stage of the maturation initiated in vivo. On the other hand, if ovulation is started in vivo on several follicles, those that are still intact invariably ovulate in vitro in several hours. 
Therefore, there may be an extraovarian relay receiving the signal of the end of oocyte maturation and, in its turn, triggering ovulation by producing the necessary mediators.

Previous follicle maturation, however, is needed for this ovulation to occur; it consists of a separation of the oocyte and its follicle envelopes, up to then united by deep microvilli through the chorion (Flügel 1964a, b). This "follicle maturation" probably takes place due to the participation of specific proteolytic enzymes, as in mammals (Espey 1974) and occurs normally at the same time as oocyte maturation.

\section{Mediators acting on ovulation in vitro}

For these studies, we were looking for substances that would induce ovulation in vitro of follicles matured in vivo (oocyte and follicle both matured).

Action of prostaglandins (Jalabert and Szöllösi 1975) - Ovulation (active expulsion of oocyte from the mature follicle) is induced by $\mathrm{PGF}_{2 \alpha}$ at doses of $1-5 \mu \mathrm{g} / \mathrm{ml}$ (Fig. 8). $\mathrm{PGE}_{2}$ is ineffective. About $18-20 \mathrm{~h}$ at $15 \mathrm{C}$ are needed for complete response. The follicular envelopes first tear open, followed by active expulsion of the oocyte. The follicle subsequently appears extremely contracted.

The response to $\mathrm{PGF}_{2 \alpha}$ is inhibited in calciumfree medium or by inhibitors of calcium influx, particularly $\mathrm{Mn}^{++}$and $\mathrm{La}^{+++}$. This suggests implication of the smooth muscle-like cells demonstrated in the theca (D. Szöllösi and B. Jalabert

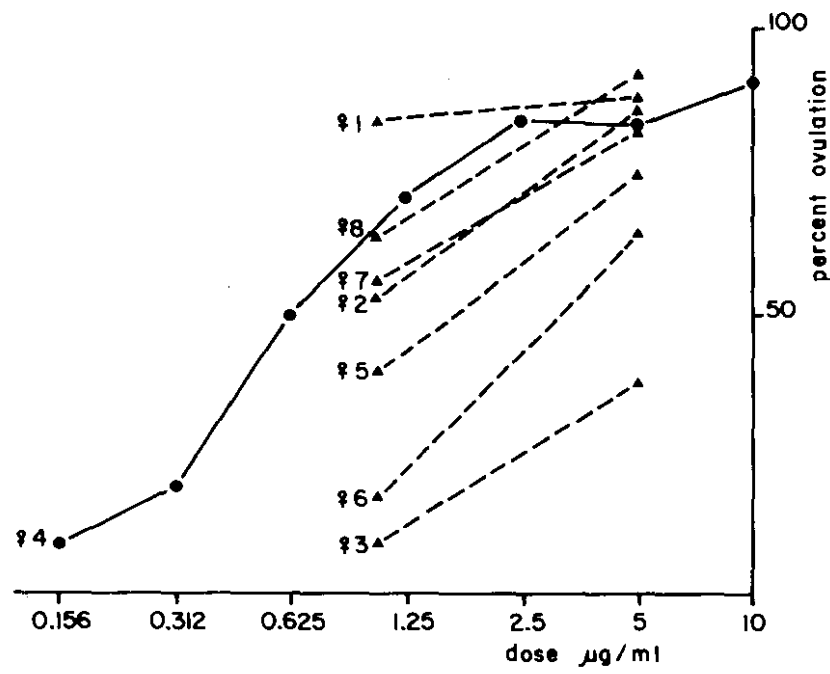

FIg. 8. Percentage of ovulation in trout follicles (eight different females) as a function of the dose of $\mathrm{PGF}_{2}$ added in vitro $18 \mathrm{~h}$ earlier, after completion of in vivo maturation. Lots of 25 follicles (from Jalabert and Szöllösi 1975). unpublished data). A significant but partial inhibition is also observed with cytochalasin B (demonstrating that contraction of cell types, other than muscle, containing actin-like filaments, may also participate in the process).

Action of catecholamines (B. Jalabert unpublished data) - Epinephrine, norepinephrine, phenylephrine, and isoproterenol, in decreasing order of effectiveness, have been shown to trigger ovulation (Fig. 9). Complete response seems slower than with $\mathrm{PGF}_{2 \alpha}$ and requires $20-24 \mathrm{~h}$ at $15 \mathrm{C}$.

\section{Action of antiadrenergic drugs on ovulating action} of $P G F_{2 \alpha}$ and epinephrine

Classification from epinephrine to isoproterenol in decreasing order of activity suggests that their action may be mediated through adrenergic receptors of the $\alpha$ type (Ahlquist 1948). Demonstration of the $\alpha$ or $\beta$ adrenergic type is more complex and requires rigorous examination (Furchgott 1967); the first stages must show that epinephrine stimulation is specific (inhibition by specific inhibitors of $\alpha$ site and no effect of $\beta$ site-specific inhibitors) and direct (not mediated through synthesis or release of another catecholamine).

Table 3 (synthesis of unpublished results) shows that $\alpha$ site inhibitors (dibenzyline, dibenamine, phentolamine) significantly stop the ovulating action of epinephrine, while $\beta$ site inhibitors are without effect. Moreover, catecholamine synthesis inhibitors ( $\alpha$-methyl-para-tyrosine or MPT, and $\alpha$-methyl-meta-tyrosine, or MMT) or storage depleting agent (MMT) exhibit no action. Thus, epinephrine action on in vitro ovulation seems to be a direct and specific action on $\alpha$-type adrenergic receptors.

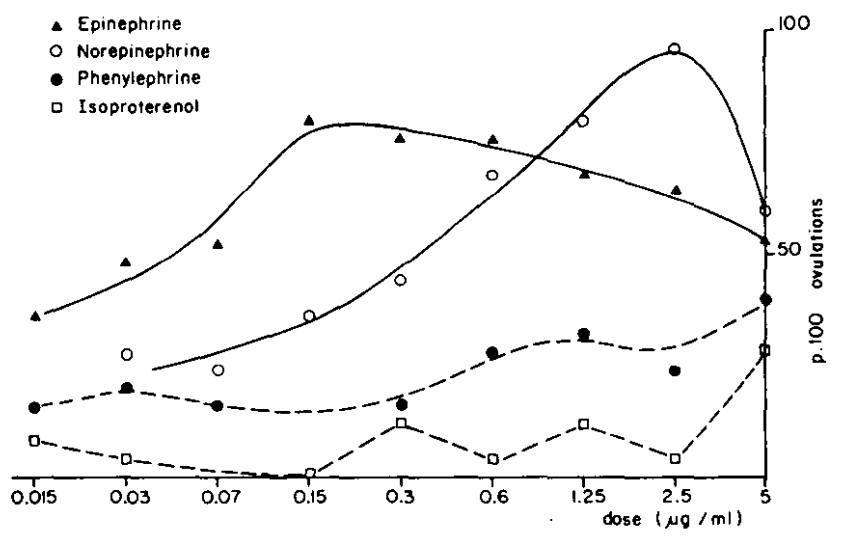

FIG. 9. Percentage of ovulations in trout follicles as a function of the dose of catecholamines added in vitro $24 \mathrm{~h}$ earlier, after completion of in vivo maturation. Lots of 25 follicles of the same female. 
TABLE 3. Effect of antiadrenergic drugs on ovulation induced in vitro with epinephrine or PGF $2 \alpha$ on rainbow trout follicles matured in vivo (B. Jalabert unpublished data). ( $\downarrow)$ inhibition or $(\uparrow)$ stimulation significant at the $5 \%(*)$, $1 \%(* *)$, or $0.01 \%(* * *)$ level of probability.

\begin{tabular}{|c|c|c|c|c|}
\hline & & & Epinephrine & $\mathrm{PGF}_{2 \alpha}$ \\
\hline & & & 0.5 to $\simeq 1 \mu \mathrm{g} / \mathrm{ml}$ & $\simeq 1$ to $\simeq 5 \mu \mathrm{g} / \mathrm{ml}$ \\
\hline \multirow{8}{*}{$\alpha$-inhibitors } & & $(100 \mu \mathrm{g} / \mathrm{ml}$ & $\downarrow * * *$ & 0 \\
\hline & Dibenzyline & $\{10 \mu \mathrm{g} / \mathrm{ml}$ & $\downarrow * * *$ & 0 \\
\hline & $\cdot 0^{\circ}$ & $1 \mu \mathrm{g} / \mathrm{ml}$ & $\downarrow * * *$ & 0 \\
\hline & Dibenamine & $\{100 \mu \mathrm{g} / \mathrm{ml}$ & $\downarrow * * *$ & 0 \\
\hline & & $10 \mu \mathrm{g} / \mathrm{ml}$ & $\downarrow * *$ & 0 \\
\hline & Phentolamine & $\{100 \mu \mathrm{g} / \mathrm{ml}$ & 0 & $\uparrow * * *$ \\
\hline & & $10 \mu \mathrm{g} / \mathrm{ml}$ & $\downarrow *$ & $\downarrow * *$ \\
\hline & Dichloroisoproterenol & $\{100 \mu \mathrm{g} / \mathrm{ml}$ & 0 & 0 \\
\hline \multirow[t]{2}{*}{$\beta$-inhibitors } & Th & $10 \mu \mathrm{g} / \mathrm{ml}$ & 0 & 0 \\
\hline & Propanolol & $\left\{\begin{aligned} 100 \mu \mathrm{g} / \mathrm{ml} \\
10 \mu \mathrm{g} / \mathrm{ml}\end{aligned}\right.$ & $\begin{array}{l}0 \\
0\end{array}$ & $\downarrow * *$ \\
\hline \multirow{4}{*}{$\begin{array}{l}\text { Cathecholamine } \\
\text { synthesis } \\
\text { inhibitors }\end{array}$} & $\alpha$ Methyl-meta-tyrosine & $100 \mu \mathrm{g} / \mathrm{ml}$ & 0 & $* 0$ \\
\hline & $(\alpha \mathrm{MMT})$ & $\int 10 \mu \mathrm{g} / \mathrm{ml}$ & 0 & 0 \\
\hline & $\alpha$ Methyl-para-tyrosine & $\{100 \mu \mathrm{g} / \mathrm{ml}$ & 0 & 0 \\
\hline & $(\alpha \mathrm{MPT})$ & $\{10 \mu \mathrm{g} / \mathrm{ml}$ & 0 & 0 \\
\hline
\end{tabular}

The effect of the same inhibitors on ovulation induced with $\mathrm{PGF}_{2 \alpha}$ is less understandable, but excludes the possibility of $\mathrm{PGF}_{2 \alpha}$ action through catecholamine synthesis and release causing stimulation of $\alpha$-adrenergic receptors and contraction.

\section{In vitro control of follicle maturation (preparation for ovulation)}

In the unsterile incubation conditions usually employed (sufficient at 10 or $15 \mathrm{C}$ for studying maturation of the oocyte protected by follicular envelopes and the chorion), ovulation cannot be triggered in vitro at the end of maturation because of alteration of the functional integrity of follicular envelopes.

On the other hand, in sterile incubation conditions (Jalabert unpublished data) ovulation can be induced in vitro by $\mathrm{PGF}_{2 \alpha}$ at the end of maturation induced by $17 \alpha-20 \beta \mathrm{Pg}$ or a gonadotropin extract (4 days of incubation at $10 \mathrm{C}$ in TBSS). By prolonged action, $17 \alpha-20 \beta$ Pg can induce follicle maturation (separation of oocyte from its follicular envelopes), as well as oocyte maturation. Then, ovulation needs the intervention of a new mediator; $\mathrm{PGF}_{2 \alpha}$ simulates this action.

b) Goldfish and pike - In goldfish and northern pike, $\mathrm{PGF}_{2 \alpha}$ is able to induce ovulation when in vitro maturation is triggered by $17_{\alpha-20 \beta} \mathrm{Pg}$ or by a fish gonadotropin extract (B. Jalabert unpublished data). Catecholamine action has not been tested.

\section{General Discussion}

The preliminary results on northern pike and goldfish do not seem to contradict the more detailed data gathered on trout as concerns the privileged role of $17 \gamma_{\alpha}-20 \beta \mathrm{Pg}$ in oocyte maturation control, the important role of corticosteroids in follicle sensitization and ovulation.

Using the results presented, we can propose a schematic model of endocrine regulation which may control oocyte maturation (Fig. 10) and ovulation (Fig. 11) in these species.

\section{Oocyte Maturation (Fig. 10)}

The left part of the diagram is classic anc corresponds in general to the well-known situa. tion in amphibians (Schuetz 1974), the main elements having been outlined by Dettlaff in 1966 . then extended to sturgeon by Dettlaff and Skoblina (1969). Only two main points are original: 1) $17 \alpha-20 \beta \mathrm{Pg}$ appears here as the most likely mediator oocyte maturation, produced by the follicular envelopes in response to gonadotropic stimulation. After testing a large number of similar natural steroids, it was found to be the most efficient (mean MED $\simeq 30 \mathrm{ng} / \mathrm{ml}$, range $5-90 \mathrm{ng} / \mathrm{ml}$ ). The minimum exposure time to obtain $100 \%$ maturation is the shortest $(30 \mathrm{~s}$ to $15 \mathrm{~min}$ ). Along with $20 \beta \mathrm{Pg}$ it is the only steroid acting directly on denuded oocytes. Finally, its presence in vivo has been shown in other Salmonidae near the time of spawning (Schmidt and Idler 1962) at mean amounts of 


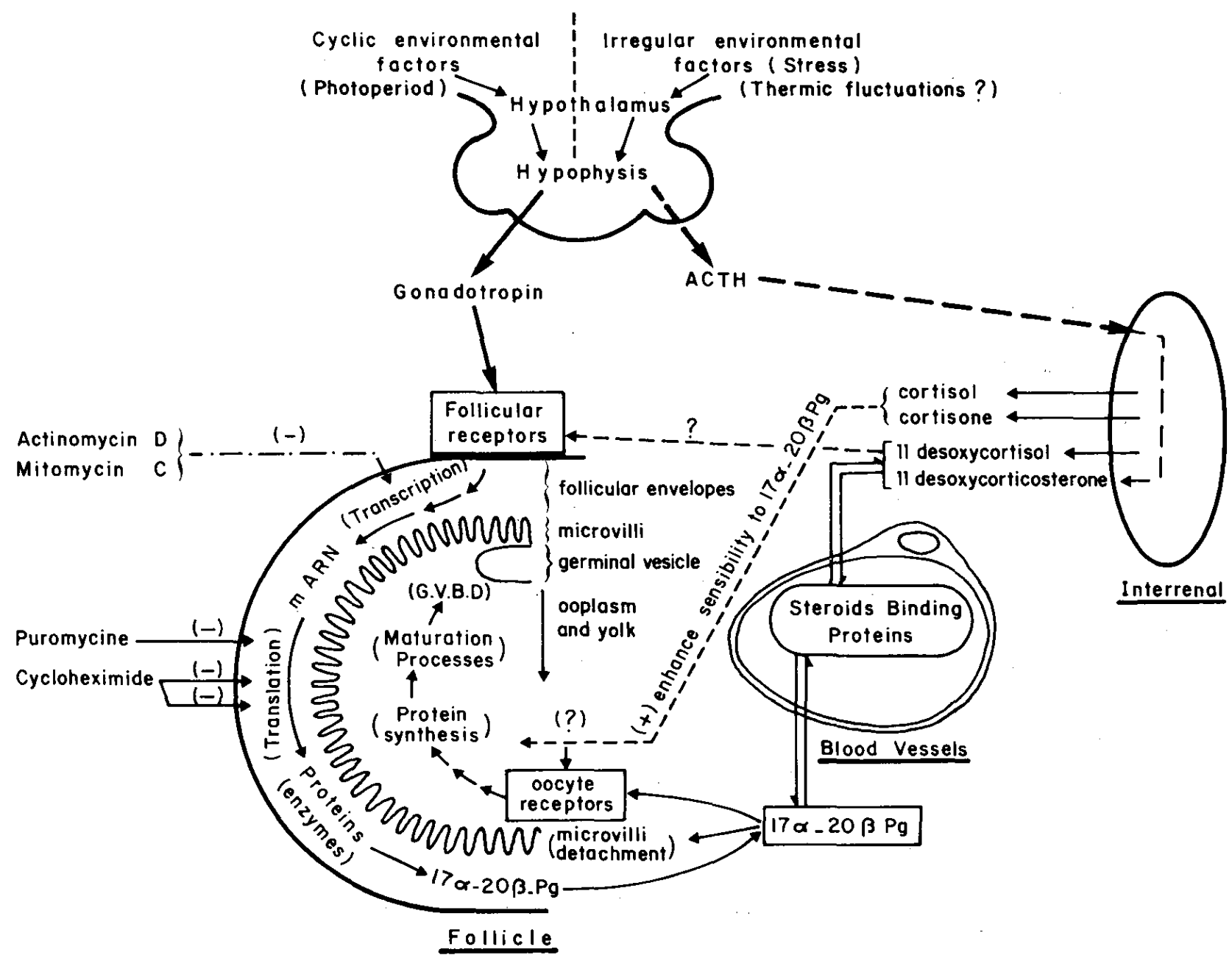

Fig. 10. Tentative scheme for the control of oocyte maturation in trout. GVBD, germinal vesicle breakdown.

about $200 \mathrm{ng} / \mathrm{ml}$ plasma, which are considerably higher than the MEDs observed in vitro. This contrast between high in vivo amounts and lower efficient doses in vitro can be explained by the existence of two protein systems in trout plasma which bind steroids; one of these of "transcortine" type binds testosterone, estradiol, corticosteroids, and progestagens, including $17 \alpha-20 \beta \mathrm{Pg}$ (Fostier and Breton 1975). Incubation in pure or diluted trout plasma raises the MED of $17 \alpha-20 \beta \mathrm{Pg}$ to physiological values (Table 4).

In vitro action of maturing steroids like progesterone (Tables 1,2 ) probably results from spontaneous metabolization into $17 \alpha-20 \beta \mathrm{Pg}$ by follicular tissue, involving neosynthesis of $\mathrm{m}-\mathrm{RNA}$ and steroidogenesis enzymes (partial inhibition by actinomycin and total inhibition with puromycin and cycloheximide (Table 2). The action is certainly not physiological because the necessary amounts are never found in vivo.
2) Puromycin does not appear to inhibit intraoocyte protein syntheses which are necessary to $17 \alpha-20 \beta$ Pg-induced maturation processes (Fig. 3 ), but it does inhibit intrafollicular protein synthesis (stage 3 in Fig. 3). Cycloheximide, on the contrary, inhibits both the processes. However, the maturation induced by progesterone in amphibians is sensitive to puromycin (Dettlaff 1966) as well as to cycloheximide (Brachet 1967) and DOC-induced maturation in catfish, $H$. fossilis, is also inhibited by these two substances (Goswami and Sundararaj 1973). This apparent peculiarity of trout oocytes may be due to either nonpenetration of the puromycin through the follicular envelopes to the oocyte, or to a peculiarity in the protein biosynthesis involved in trout maturation.

The right side of Fig. 10 primarily shows the possible participation of corticosteroids, as shown by the results presented and the existence of 


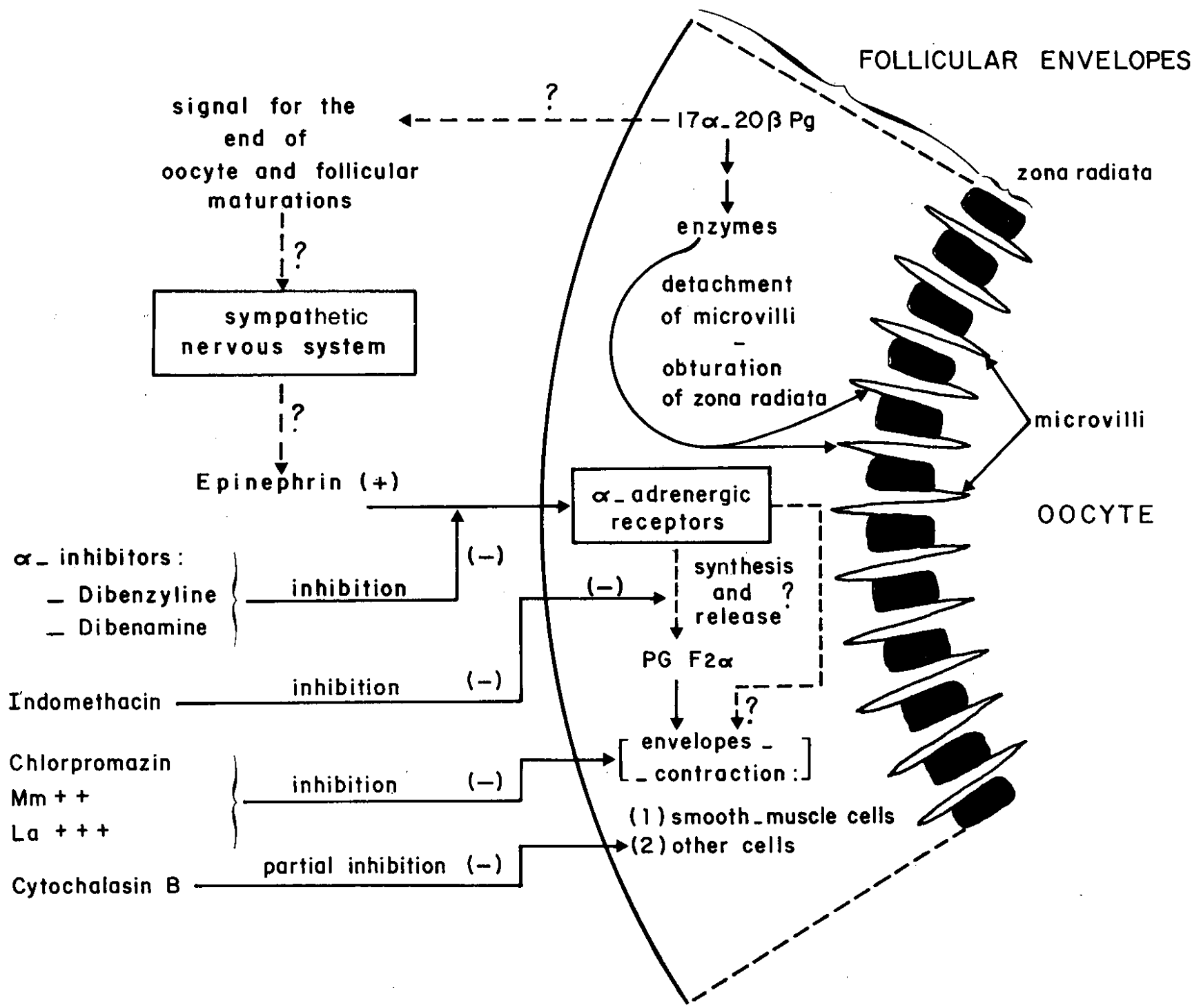

FIG. 11. Tentative scheme for the control of ovulation in trout.

binding proteins in the plasma (Fostier and Breton 1975). These corticosteroids are probably produced mainly by the interrenal organ, but Colombo et al. (1973) showed that the ovaries of some fishes can also produce them. Taking into account that their efficacy is much less than that of $17 \alpha_{-}-20 \beta \mathrm{Pg}$ in rainbow trout, goldfish, and northern pike, and that they do not affect the naked trout oocyte, their action seems to be indirect.

It has been shown (Jalabert 1975) that cortisol and cortisone considerably increase overall follicle sensitivity to gonadotropin, and especially oocyte sensitivity to $17 \alpha-20 \beta \mathrm{Pg}$; they are practically unbound by trout plasma (Fostier and Breton 1975); thus, any change in interrenal secretion could affect the ovary without buffer effect. On the other hand, 11-deoxycortisol and 11-deoxycorticosterone oscillations may be buf- fered by fixation to plasma proteins, but they may play an indirect role by displacing the bound $17 \alpha_{\alpha}-20 \beta \mathrm{Pg}$ and triggering oocyte maturation in absence of a typical gonadotropic discharge.

It appears, then, that there are two possible routes for triggering oocyte maturation:

1) A direct gonadotropic route, which would consist of an "ovulating discharge" of pituitary gonadotropic hormone comparable to that shown in goldfish (Breton et al. 1972). This gonadotropic discharge would then cause an increase of $17 \alpha-20 \beta \mathrm{Pg}$ produced by the follicle sufficient to saturate both the plasma bonds and oocyte receptors;

2) An indirect corticotropic route. This route would function without any typical gonadotropin discharge (plasma gonadotropin level is high anyway at the end of vitellogenesis, Breton et al. 
TABLE 4. Reduction of $17 \alpha-20 \beta \mathrm{Pg}$ efficiency on in vitro intrafollicular maturation of trout oocytes by incubation in trout plasma (from Fostier and Breton 1975).

\begin{tabular}{clc}
\hline \hline No. female & Incubation medium & Median Efficient Dose \\
\hline 1 & $\begin{array}{l}\text { Balanced salt solution } \\
\text { Carbon-treated plasma } \\
\text { (nondiluted) }\end{array}$ & $25.1(20.7-30.6)$ \\
2 & $\begin{array}{l}\text { Balanced salt solution } \\
\text { Carbon-treated plasma } \\
\text { (nondiluted) }\end{array}$ & $7.9(6.7-9.3)$ \\
& $\begin{array}{c}\text { Balanced salt solution } \\
\text { Carbon-treated plasma } \\
\text { Diluted 1/10 } \\
\text { Carbon-treated plasma } \\
\text { (nondiluted) }\end{array}$ & $120 .(108-132)$ \\
& & $12.2(7.6-19.5)$ \\
& & $122(110-134)$ \\
\hline
\end{tabular}

1976a) after a simple increase in blood corticosteroid level. These corticosteroids could either partially displace plašma equilibrium between protein-bound $17 \alpha-20 \beta \mathrm{Pg}$ and free $17 \alpha-20 \beta \mathrm{Pg}$ (action of 11-deoxycortisol and 11-deoxycorticosterone), or lower oocyte sensitivity threshold to $17 \alpha-20 \beta \mathrm{Pg}$ (action of cortisol and cortisone), or conjugate these two effects. This hypothesis seems all the more probable :as a rise in cortisone or cortisol secretion was observed in salmon during sexual maturation (Donaldson and Fagerlund 1968, 1970; Fagerlund and Donaldson 1970). Spawning in many fishes is often related to temporary perturbation in the environment; this "environmental stress" could cause an increase in corticosteroid level, hastening triggering of maturation and ovulation.

These routes may be complementary, or, on the contrary, one may predominate the other, depending on the species or in the same species according to environmental conditions.

The principal difference between the model proposed here and the model for catfish, $H$. fossilis (Sundararaj and Goswami 1966a, b, 1971; Goswami and Sundararaj 1971a, b; Sundararaj et al. 1972a; Sundararaj et al. 1972b; Sundararaj and Goswami 1974) is the role of the interrenal. In catfish, the interrenal organ seems to play the role of compulsory gonadotropin relay, whereas in rainbow trout, goldfish, and northern pike, it seems to offer an independent regulation. route which probably remains under corticotropin control. This is the case in the sockeye salmon, $O n$ corhynchus nerka (Donaldson and McBride 1974).

Most of the results on $H$. fossilis are not incompatible with the model proposed here. Nonresponse to gonadotropic hormone in vitro in this species (Goswami and Sundararaj 1971; Sun- dararaj et al. 1972b) could result from absence of in vitro sensitivity by physiological amounts of corticosteroids. For that reason, the absence might be compensated for in co-culture with interrenal fragments, producing the positive effect of the o-LH observed on intrafollicular maturation (Sundararaj and Goswami 1974). The only definite proof placing $H$. fossilis in one or the other of the models would be furnished by a study of the secretory pattern of the interrenal organ in vitro in presence of either fish ACTH or a purified fish gonadotropin in order to determine whether or not that organ could actually be a gonadotropic relay.

\section{OvUlation (Fig. 11)}

Our results on ovulation show that its in vitro control can be dissociated from control of oocyte maturation in rainbow trout, goldfish, and northern pike. On the other hand, in $H$. fossilis (Goswami and Sundararaj 1971a, b) and in $O$. latipes (Hirose 1971, 1972; Iwamatsu 1974); maturation and ovulation take place consecutively in vitro following gonadotropic or steroid stimulation.

In rainbow trout, we have shown that ovulation, strictly speaking (expulsion of the oocyte from the follicle), needs previous follicular maturation (follicular envelope detachment from the oocyte), which can be triggered in vitro by prolonged $17 \alpha-20 \beta \mathrm{Pg}$ action, and which occurs simultaneously with oocyte maturation. Ovulation itself may be experimentally induced in vitro by $\mathrm{PGF}_{2 \alpha}$ or catecholamines (epinephrine).

Stacey and Pandey (1975) have shown in goldfish that prostaglandins were probably implicated in the ovulation process: indomethacine 
inhibits ovulation in vivo triggered by an $\mathrm{HCG}$ injection combined with a rise in temperature; the injection of prostaglandins $\mathrm{PGF}_{2 \alpha}, \mathrm{PGE}_{1}$ or $\mathrm{PGE}_{2}$ can overcome this inhibition. The ovulating action of $\mathrm{PGF}_{2 \alpha}$, which we see in vitro, thus has a true physiological basis. In mammals, the participation of prostaglandins in the ovulation process is now well-established (see articles reviewed by Stacey and Pandey 1975; Jalabert and Szöllösi 1975).

Our results on epinephrine action seem to favor the hypothesis that it is mediated through receptor sites of $\alpha$-adrenergic type. Similar hypotheses have already been recently formulated on the ovulation mechanism in rabbit (Nalbandov et al. 1973) and in hen (Kao and Nalbandov 1972), using techniques in which adrenergic or antiadrenergic drugs are injected intrafollicularly. However, as Kao and Nalbandov (1972) emphasize, the physiological properties of these drugs have been established on mammalian tissue and not on the ovaries of mammals, birds, and in our case, fish. Moreover, while sympathetic innervation of the ovary has been well-shown in mammals and birds (Bahr et al. 1974), there are no similar observations in fish. However, from in vitro experiments showing that the link between oocyte maturation and ovulation necessitates an extraovarian relay, we have sufficient data to propose the following working hypothesis:

The relay between maturation and ovulation could be the sympathetic nervous system receiving an end-of-maturation signal and then inducing stimulation of $\alpha$-adrenergic receptor sites of ovary and follicle. These would then trigger synthesis and (or) release of prostaglandins acting on the contraction of follicular envelopes.

\section{Summary}

\section{Oocyte Maturation}

In rainbow trout, a number of indirect experimental arguments indicate $17 \alpha$-hydroxy-20 $\beta$-dihydroprogesterone $(17 \alpha-20 \beta \mathrm{Pg})$ as the most probable mediator of oocyte maturation. This mediator could be produced by follicular envelopes in response to hypophyseal gonadotropin action. In northern pike and goldfish, $17 \alpha-20 \beta \mathrm{Pg}$ is also the most efficient steroid in triggering intrafollicular oocyte maturation in vitro.

In these three species, cortisol increases overall follicular sensitivity to gonadotropic extract action in vitro. From results obtained in rainbow trout, this argument would seem to be based on sensitization of oocytes to $17 \alpha-20 \beta \mathrm{Pg}$ action. This observation leads to the hypothesis of a 2-way control triggering maturation: a direct gonadotropic route and an indirect corticotropic route.

\section{OvUlation}

In rainbow trout, northern pike, and goldfish, ovulation (expulsion of the mature oocyte from the follicle) may be triggered in vitro by $\mathrm{PGF}_{2 \alpha}$ action on mature follicles. Results obtained in rainbow trout show that epinephrine also acts on ovulation in vitro by a mechanism involving activation of $\alpha$-adrenergic receptor sites. The possible interrelations between these mediators are discussed.

\section{Acknowledgments}

I wish to thank J. Marcel, who typed the manuscripts, A. Daifuku, who translated this text, and R.-F. Masson, who drew the diagram and figures.

ALQuist, R. P. 1948. A study of the adrenoreceptors. Am. J. Physiol. 153: 586-592.

Bahr, J., L. KaO, and A. V. Nalbandov. 1974. The role of catecholamines and nerves in ovulation. Biol. Reprod. 10: $273-290$.

BRACHET, J. 1967. Effects of actinomycin, puromycin and cycloheximide upon maturation of Amphibian oocytes. Exp. Cell Res. 48: 233-236.

Breton, B., R. Billard, B. Jalabert, and G. KanN. 1972. Dosage radioimmunologique des gonadotropines plasmatiques chez Carassius auratus au cours du nycthémère et pendant l'ovulation. Gen. Comp. Endocrinol. 18: 463-468.

Breton, B., B. Jalabert, A. Fostier, and R. Billard. 1976a. Étude sur le cycle reproducteur de la Truite arc-en-ciel et de la Tanche. Effet de variations expérimentales de la température. J. Physiol. Paris (In press)

Breton, B., B. Jalabert, and P. Reinaud. 1976 b. Purification of gonadotropin from rainbow Trout (Salmo gairdnerii Richardson) pituitary glands. Ann. Biol. Anim. Biochim. Biophys. (In press)

Cameron, J. N., AND D. J. Randall. 1972. The effects of increased ambient $\mathrm{CO}_{2}$ tension, $\mathrm{CO}_{2}$ content, and $\mathrm{pH}$ in rainbow trout. J. Exp. Biol. 57: 671-680.

Colombo, L., H. A. Bern, J. Pieprzyk, and D. W. JoHnson. 1973. Biosynthesis of 11-desoxycorticosteroids by teleost ovaries and discussion of their possible role in oocyte maturation and ovulation. Gen. Comp. Endocrinol. 21: 168-178.

DettlafF, T. A. 1966. Action of actinomycin and puromycin upon frog oocyte maturation. J. Embryol. Exp. Morphol. 16: 183-185.

DetTlaff, T. A., and M. N. Skoblina. 1969. The role of germinal vesicle in the process of oocyte maturation in Anura and Acipenseridae. Ann. Embryol. Morph. Suppl. 1: 133-151.

Donaldson, E. M., and U. H. M. Fagerlund. 1968. Changes in the cortisol dynamics of sockeye salmon 
(Oncorhynchus nerka) resulting from sexual maturation. Gen. Comp. Endocrinol: 11: 552-561.

1970. Effect of sexual maturation and gonadectomy at sexual maturity on cortisol secretion rate in sockeye salmon (Onchorhynchus nerka). J. Fish. Res. Board Can. 27: 2287-2296.

Donaldson, E. M., AND J. R. MCBRide. 1974. Effect of ACTH and salmon gonadotropin on interrenal and thyroid activity of gonadectomized adult sockeye salmon (Onchorhynchus nerka). J. Fish. Res. Board Can. 31: 1211-1214.

EsPeY, L: L. 1974. Ovarian proteolytic enzymes and ovulation. Biol. Reprod. 10: 216-235.

Fagerlund, U. H. M., and E. M. Donaldson. 1970. Dynamics of cortisone secretion in sockeye salmon (Onchorhynchus nerka) during sexual maturation and after gonadectomy. J. Fish. Res. Board Can. 27: 2323-2331.

FlügEl, H. 1964a. Electron microscopic investigations on the fine structure of the follicular cells and the zona radiata of trout oocytes during and after ovulation. Naturwissenschaften 23: 564-565.

1964b. Desmosomes in the follicular epithelium of growing oocytes of the eastern brook trout (Salvelinus fontinalis) (Electron microscopic investigations) Naturwissenschaften 23: 566.

Fostier, A., AND B. Breton. 1975. Binding of steroids by plasma of a teleost: the rainbow trout Salmo gairdnerii. J. Steroid Biochem. 6: 345-351.

Fostier, A., B. JAlabert, AN D M. Terqui. 1973. Action prédominante d'un dérivé hydroxylé de la progestérone sur la maturation in vitro des ovocytes de la Truite arc-en-ciel Salmo gairdnerii. C. R. Acad. Sci. 277: $421-424$.

FURCHGOTT, R. F. 1967. The pharmacological differentiation of adrenergic receptors. Ann. N. Y. Acad. Sci. 139: 553-570.

Goswami, S. V., and B. I. Sundararaj. 1971a. Temporal effects of ovine luteinizing hormone and desoxycorticosterone acetate on maturation and ovulation of oocytes of the catfish Heteropneustes fossilis Bloch. An in vivo and in vitro study. J. Exp. Zool. 178: 457-466.

1971 b. In vitro maturation and ovulation of oocytes of the catfish Heteropneustes fossilis Bloch. Effects of mammalian hypophyseal hormones, catfish pituitary homogenate, steroid precursors and metabolites, and gonadal and adrenocortical steroids. J. Exp. Zool. 178: 467-478.

1973. Effect of actinomycin D, mitomycin C, puromycin and cycloheximide on desoxycorticosterone induced in vitro maturation in oocytes of the catfish, Heteropneustes fossilis Bloch. J. Exp. Zool. 185: $327-332$

Hirose, K. 1971. Biological study on ovulation in vitro of fish. I - Effects of pituitary and chorionic gonadotropins on ovulation in vitro of Medaka Oryzias latipes. Bull. Jpn. Soc. Sci. Fish. 3: 585-591.

1972. Biological study on ovulation in vitro of fish. IV - Induction of in vitro ovulation in Oryzias latipes oocyte using steroids. Bull. Jpn. Soc. Sci. Fish. 38: 457-463.

Hirose, K., and E. M. Donaldson. 1972. Biological study on ovulation in vitro of fish. III - The induction of in vitro ovulation of Oryzias latipes oocytes using salmon pituitary gonadotropin. Bull. Jpn. Soc. Sci. Fish. 38: 97-100.

IwAMATSU, T. 1974. Studies on oocyte maturation of the Medaka Oryzias latipes. II - Effects of several steroids and calcium ions and the role of follicle cells on in vitro maturation. Anat. Zool. Jpn. 47, 30-42.

JaLABERT, B. 1975. Modulation par différents stéroïdes non maturants de l'efficacité de la $17 \alpha$-hydroxy, $20 \beta$-dihydroprogestérone ou d'un extrait gonadotrope sur la maturation intrafolliculaire in vitro des ovocytes de la Truite arc-en-ciel Salmo gairdnerii. C. R. Acad. Sci. Paris 281: 811-814.

JALABERT, B., AND B. BRETON. 1973. In vitro maturation of pike (Esox lucius) oocytes. Gen. Comp. Endocrinol. 22: 391 (Abstr)

Jalabert, B., B. Breton, AND R. Billard. 1974. Dosage biologique des hormones gonadotropes de Poissons par le test de maturation in vitro des ovocytes de Truite. Ann. Biol. Anim. Biochim. Biophys. 14: 217-228.

JALABERT, B., B. Breton, AND C. Bry. 1972. Maturation et ovulation in vitro des ovocytes de la Truite arc-enciel Salmo gairdnerii. C. R. Acad. Sci. Paris 275: $1139-1142$.

Jalabert, B., C. Bry, D. Szöllösi, and A. Fostier. 1973. Etude comparée de l'action des hormones hypophysaires et stéroides sur la maturation in vitro des ovocytes de la Truite et du Carassin (Poissons téléostéens). Ann. Biol. Anim. Biochim. Biophys. 13: $59-72$.

JALABERT, B., AND D. Szöllösı. 1975. In vitro ovulation of trout oocytes: effect of prostaglandins on smooth muscle-like cells of the theca. Prostaglandins 9: 765-778.

KaO, L. W. L., and A. V. Nalbandov. 1972. The effect of antiadrenergic drugs on ovulation in Hens. Endocrinology 90: 1343-1349.

KIRSHENBLATT, I. D. 1959. Effect of cortisone on ovaries of the Loach (russe; résumé anglais). Bull. Exp. Biol. Med. USSR 83: 629-632.

Nalbandov, A. V., L. W. L. KaO, and E. E. Jones. 1973. Effects of intrafollicular injection of hormones and drugs. J. Reprod. Fertil. Suppl. 18: 15-22.

SCHMIDT, P. J., AND D. R. IDLER, 1962. Steroid hormones in the plasma of salmon at various states of maturation. Gen. Comp. Endocrinol. 2: 204-2 14.

SchuetZ, A. W. 1974. Roles of hormones in oocyte maturation. Biol. Reprod. 10: 150-178.

SundararaJ, B. I., T. C. ANAND, AND E. M. DONALDSON. 1972a. Effects of partially purified salmon pituitary gonadotrophin on ovarian maintenance, ovulation and vitellogenesis in the hypophysectomized catfish Heteropneustes fossilis Bloch. Gen. Comp. Endocrinol. 18: 102-114.

Sundararaj, B. I. , AND S. V. Goswami. 1966a. Effects of mammalian hypophysial hormones, placental gonadotrophins, gonadal hormones and adrenal corticosteroids in ovulation and spawning in hypophysectomized catfish Heteropneustes fossilis Bloch. J. Exp. Biol. 161: 287-296.

1966b. Effect of metopiron (SU 4885) on luteinizing hormone and corticosteroid-induced ovulation and 
spawning in hypophysectomized catfish Heteropneustes fossilis Bloch. J. Exp. Zool. 163: 49-54.

1971. Effects of desoxycorticosterone and hydrocortisone singly and in various combinations on in vitro maturation of oocytes of the catfish Heteropneustes fossilis Bloch. Gen. Comp. Endocrinol. 17: 570-573.

1974. Effects of ovine luteinizing hormone and porcine adrenocorticotropin on maturation of oocytes of the catfish Heteropneustes fossilis Bloch, in ovary- interrenal coculture. Gen. Comp. Endocrinol. 23: 276-281.

Sundararaj, B. I., S. V. Goswami, and E. M. DONALDSON. 1972b. Effect of salmon gonadotropin on in vitro maturation of oocytes of a catfish Heteropneustes fossilis. J. Fish. Res. Board Can. 29: 435-437.

Stacey, N. E., And S. Pandey. 1975. Effects of indomethacin and prostaglandins on ovulation of goldfish. Prostaglandins 9: 597-608. 